\title{
Cross-Disciplinary Faculty Perspectives On Experiential Learning
}

Alvin Rosenstein, Adelphi University, USA

Catherine Sweeney, Contract Pharmaceutical Corporation, USA

Rakesh Gupta, Adelphi University, USA

\begin{abstract}
An on-line survey was conducted among a university's department chairs in an effort to gain perspective on university-wide use of Experiential Learning (EL). While there were differences in cross-disciplinary definitions and perspectives regarding EL, ninety-one per cent of 35 department chairs indicated their department made use of EL with greatest use during the junior and senior years. EL is defined generally as a hands-on experience and/or learning by doing while cognitive activity, such as observation and reflection, is included in the definition by a third of the chairs. Eighty-eight per cent of the chairs believe students view EL as either "very beneficial" or "beneficial".
\end{abstract}

Keywords: Experiential Learning; Action Learning; Pedagogy; Curriculum

\section{INTRODUCTION}

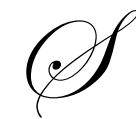

cholars extending from Aristotle, who said, "What we have to learn to do, we learn by doing, " and Confucius, who observed that "I see and I remember, I do and I understand" (Koo, 1999), to contemporary educators and psychologists, have long emphasized the pedagogical merits of experiential learning or "learning by doing," hereafter referred to as EL.

John Dewey, the towering giant of educational philosophy in the past century and the originator of the practice of student teaching, emerged as an influential crusader, who emphasized the critical importance of EL as an pedagogical tool (Dewey, 1915, 1916, 1938). His influence upon subsequent generations of educators has been profound (Kolb \& Kolb, 2005; President's Commission, 2001).

Today most business and professional institutions take cognizance of the importance of EL via training workshops and similar programs, designed to insure "on-the-job" competency (Dotlich \& Noel, 1998; Vicere \& Fulmer, 1998). Educators in fields such as education, medicine, and law, all have institutionalized EL in the form of student teaching, internships, clerkships and the like. However, other traditional fields of study have been slow to embrace EL in their curricula and many do not embrace the practice at all.

Adelphi University, recognizing the importance of EL, has facilitated its incorporation into many degree programs. The professional schools of Education, Nursing, Psychology and Social Work already enjoy a long history of EL. Over the past six years, its Business School has initiated a program of selective implementation and research with a form of EL referred to as "Action Learning" (Rosenstein, Gupta \& Ashley, 2004; Gupta, Ashley \& Rosenstein, 2005; Rosenstein, Gupta \& Ashley, 2006; Rosenstein, Ashley, Gupta \& Ulin (2008).

In an effort to gain additional perspective regarding the university-wide employment of EL, the university created a task force to study the issue. This article summarizes the results of an on-line survey conducted among all department Chairs, in order to assess cross-disciplinary perceptions, attitudes, and use of EL across the university. 


\section{METHOD}

The on-line survey administered to all of the university's 36 department chairs \& program heads, elicited responses from 35 , for a $97.2 \%$ completion rate.

Programs/Departments that responded to the survey:

Anthropology

Art and Art History

Biology

Business--3

Center for Career Development

Center For International Education

Communication Sciences and Disorders/Speech and Hearing Center

Communications

Curriculum and Instruction--2

Dance

Derner Doctoral Program in Clinical Psychology

Derner Institute for Advanced Psychological Studies

Early Childhood Education and Special Education

English

Environmental Studies

Health, Physical Education \& Human Performance

Honors College

Languages and International Studies

LGS

Management

Marketing

Nursing

Office of School and Community Partnerships

Political Science

School Psychology

Social Work

Social Work [graduate]

Social Work [BSW]

Sociology

Special Education Program

University College

\section{HIGHLIGHTS OF THE FINDINGS} findings.

The responses to following nine questions, with accompanying comments, summarize the major survey

\section{Define Experiential Learning as it applies to your curriculum:}

1. Learning by doing/Hands on (general)

Base $=35 \quad$ Number Percentage * Internship

Laboratory

Field

Net $=$ those who cited at least one of the above

2. Cognitive Experience (Reflection/Observation)

3. Real World Experience (General)

* Multiple mentions permitted

$\begin{array}{rr}18 & 51 \% \\ 7 & 20 \% \\ 3 & 9 \% \\ 1 & 3 \% \\ \underline{28} & \underline{80 \%} \\ \underline{10} & \underline{29 \%} \\ \underline{6} & \underline{6 \%}\end{array}$


Comments:

i. Roughly 4 out of 5 define experiential learning in terms of learning-by-doing activities.

ii. Roughly 3 out of 10 (also or alternatively) define it in terms of cognitive activities such as observation and/or reflection.

II. What is the purpose of Experiential Learning?

$$
\text { Base }=35 \quad \text { Number Percentage * }
$$

1. Learning by doing/Hands on (general)

Provide Practical Application

Increase Skills

Net $=$ those who cited at least one of the above

2. Increase Understanding

3. Provide Real World Experience

4. Development and Growth

5. Connect to Real World

6. Confirm Career

$\begin{array}{rr}7 & 20 \% \\ 8 & 23 \% \\ 2 & 6 \% \\ \frac{16}{11} & \underline{46 \%} \\ \frac{31 \%}{\underline{6}} & \frac{\underline{17 \%}}{\underline{5}} \\ \underline{\underline{2}} & \underline{14 \%} \\ \underline{1} & \underline{6 \%}\end{array}$

Comments:

i. Close to one-half say the purpose is to provide hands on experience.

ii. Roughly one-third say purpose is to increase understanding.

III. Is Experiential Learning part of your curriculum?

Base $=34 \quad$ Number Percentage

Yes

No

$\begin{array}{rr}31 & 91 \% \\ 3 & 9 \%\end{array}$

Comments:

i. The vast majority say they provide Experiential Learning.

IV. When do students participate in Experiential Learning?

$$
\text { Base }=32 \quad \text { Number Percentage }
$$

Freshman Year

$16 \quad 50 \%$

Sophomore Year

$18 \quad 56 \%$

Junior Year

$24 \quad 75 \%$

Senior Year

$24 \quad 75 \%$

Graduate School

22

$67 \%$

Comments:

i. Experiential Learning occurs in all years, with greatest emphasis in the Junior and Senior years.

ii. 
V. Description of Experiential Learning activities in the curriculum:

$$
\text { Base }=30 \quad \text { Number Percentage* }
$$

1. Learning by doing (general)

$\begin{array}{rr}12 & 34 \% \\ 12 & 34 \% \\ 4 & 11 \% \\ 2 & 5 \% \\ \underline{23} & \underline{66 \%} \\ \underline{8} & \underline{23 \%} \\ \underline{1} & \underline{3 \%}\end{array}$

Comments:

Field/Laboratory

Internship

Application of knowledge

Net $=$ those who cited at least one of the above

2. Cognitive activities (Reflection/Observation)

3. Case Studies
$11 \%$

$5 \%$

$23 \%$

$\underline{3 \%}$

i. Roughly two-thirds provide activities involving learning by doing.

ii. Roughly one-fourth provide cognitive activities.

VI. Do you assess Experiential Learning in your program?

Base $=29 \quad$ Number Percentage

Yes

No

$22 \quad 76 \%$

$7 \quad 24 \%$

Comments:

i. Roughly three-fourths say they assess EL in their program.

VII. Who conducts the assessment?

Base $=26 \quad$ Number Percentage*

Faculty

Students

Chair/Director
$23 \quad 84 \%$

$8 \quad 31 \%$

$12 \quad 46 \%$

Comments:

i. Assessment is primarily conducted by faculty and chairs/directors.

ii. Roughly one-third have students participate in assessment.

VIII. Chairs' opinion of students' reactions to Experiential Learning:

$$
\text { Base }=32 \quad \text { Number Percentage }
$$

Very Beneficial

Beneficial

Neutral

Not Beneficial

Very Unbeneficial
$20 \quad 63 \%$

$8 \quad 25 \%$

$2 \quad 6 \%$

$0 \quad 0 \%$

$26 \%$

Comments:

i. Roughly 9 out of 10 believe students view EL as very beneficial or beneficial. 


\title{
IX. Description of impact of Experiential Learning on students:
}

$$
\text { Base }=32 \quad \text { Number Percentage }
$$

\author{
Didn't Assess \\ Appreciate/Happy \\ Increase Skills \\ Increase Understanding \\ Gained Employment \\ Confirmed Career Path
}

$\begin{array}{rr}17 & 53 \% \\ 11 & 34 \% \\ 7 & 22 \% \\ 7 & 22 \% \\ 2 & 6 \% \\ 1 & 3 \%\end{array}$

Comments:

i. Although three-fourths claimed to assess programs, roughly half did not provide any feedback on assessment.

ii. One-third said students appreciated or were happy about their experiential learning experience.

iii. One-fifth said experiential learning increased skills.

iv. One-fifth said experiential learning increased understanding.

\section{DISCUSSION}

Not surprisingly, EL is generally defined (by 80\%), as a hands-on experience and/or learning by doing. In addition, cognitive activity, such as observation and reflection, is (also) included in the definition by a third of the chairs. Perhaps the most unanticipated finding regards the wide-spread use (91\%) of EL, as defined by the faculty. It is used throughout the school experience, with greatest use during the junior and senior years $(75 \%)$. Close to nine out of ten $(88 \%)$ chairs believe students view EL to be either "very beneficial" or "beneficial." However, only half provided any feedback on EL assessment and the procedures used apparently varied greatly. While the widespread use and favorable opinion of EL among department chairs underscores its apparent value as a pedagogical tool, the findings suggest a need for more systematic assessment and perhaps further investigation of how EL might be best applied in the individual academic disciplines.

\section{AUTHOR INFORMATION}

Alvin Rosenstein is Professor of Marketing at Adelphi University's School of Business. Over the past decade, he and his colleagues have implemented and researched a continuing program of Action Learning (a form of EL). He has been twice selected as a nominee for the presidency of the Division of Consumer Psychology of the American Psychological Association. E-mail: rosenste@adelphi.edu. Corresponding author.

Catherine Sweeney completed her undergraduate degree in Psychology as well as her MBA at Adelphi University. As an undergraduate, a Model Strategic Plan she developed was published in A. Rosenstein \& D. Rosenstein's How To Develop Successful Marketing Strategies. Catherine was also a Captain Lifeguard for the Town of Hempstead and now works for the Contract Pharmaceutical Corporation. E-mail: catherinesweeney@ mail,adelphi.edu

Rakesh Gupta, a former electrical engineer and management faculty, is currently Dean of the School of Business at Adelphi University. His research interests are in strategic management, with a focus on business ethics, action learning, financial literacy, and management of technology. E-mail: gupta@adelphi.edu

\section{REFERENCES}

1. Dewey, John (1915). The School and Society. Chicago: University of Chicago Press.

2. Dewey, John (1916). Democracy \& Education. New York: MacMillan.

3. $\quad$ Dewey, John (1938). Education \& Experience. New York: Simon \& Schuster.

4. Dotlich, David and Noel, James (1998). How the World's Top Companies are Re-Creating Their Leaders and Themselves. San Francisco: Jossey Bass. 
5. Gupta, R., Ashley, A. \& Rosenstein, A. (2005). "Implementing Action Learning in Marketing Research Courses." Proceedings of Northeast Decision Sciences Institute, May 2005.

6. Kolb, A. and Kolb, D. (2005). "Learning Styles and Learning Spaces: Enhancing Experiential Learning in Higher Education.” Academy of Management Learning \& Education, Vol. 4, No. 2.

7. Koo, L. C. (1999). "Learning Action Learning.” Journal of Workplace Learning, Vol. II, No. 3.

8. President's Commission on Undergraduate Educational Life (2001). Education through experience: A report to the President of Case Western University from the President's Commission on Undergraduate Education and Life. Cleveland, $\mathrm{OH}$ : Case Western Reserve.

9. Rosenstein, Gupta, \& Ashley (2004). "Action learning: A “new” teaching tool for undergraduate business education," Journal of College Teaching \& Learning, Vol. 1, No. 5.

10. Rosenstein, Gupta, \& Ashley (2006). “A Qualitative Analysis of Students' Attitudes towards Action Learning," Journal of College Teaching \& Learning, Vol. 3, No. 11.

11. Rosenstein, Ashley, Gupta, \& Ulin (2008). "Attitudes Regarding Action Learning," American Journal of Business Education, Vol. 1, No. 2.

12. Rosenstein, A. \& Rosenstein, D. (2009). How to Develop Successful Marketing Strategies: Understanding, Developing and Managing the Process, (2nd Ed). Deer Park, NY: Linus Publications.

13. Vicere, A. V. and Fulmer, R. M. (1998). Leadership by Design. Boston, MA: Harvard Business School Press. 